\title{
TERRORIST ACTIVITIES AND CAPITAL FLOWS OF DEVELOPED COUNTRIES*
}

\author{
Tomislav GALOVIĆ - Heri BEZIĆ - Petar MIŠEVIĆ \\ (Received: 18 October 2017; revision received: 19 February 2018; \\ accepted: 27 February 2018)
}

The main aim of this paper is to measure the consequences of terrorist activities on capital flows of the developed countries. Capital flows are interpreted as FDI inflows and outflows. The methodology is based on the dynamic panel data models (System-2 step-GMM estimator) using a sample of 36 developed countries all over the world from 2000 to 2016 . The key results indicate that the terrorist incidents have different impact on capital flows of the developed countries compared to impacts of economic and institutional variables. All the variables used in the paper show the level of their impact on capital flows. The results indicate that terrorist activities weaken economic activity of a country, while minimising capital flows in certain situations. The recommendations and proposals are given based on the results of research.

Keywords: developed countries, capital flows, international competitiveness, terrorist activities

JEL classification indices: F21, F52, F59, F62

* Research has been fully supported by the University of Rijeka under the project number 18.02.2.2.01 and 13.02.1.3.13.

Tomislav Galović, corresponding author. Assistant Professor, Faculty of Economics, University of Rijeka, Croatia. E-mail: tgalovic@efri.hr

Heri Bezić, Full Professor, Faculty of Economics, University of Rijeka, Croatia.

E-mail: heri.bezic@efri.hr

Petar Mišević, Assistant Professor, Croatian Chamber of Commerce, Zagreb, Croatia.

E-mail: pmisevic@hgk.hr 


\section{INTRODUCTION}

Due to its relevance, terrorism has become a popular subject within scientific, political and social sphere. Terrorist incidents in the developed countries of the European Union (EU), such as Germany (2016), France (2015 and 2016), Belgium (2016), Spain (2017) and the UK (2017) emphasised the relevance of terrorism prevention by strengthening national security activities.

According to Shahzad et al. (2016), a terrorist act represents the use (or threat) of violence against noncombatant targets by illegal organisations to induce fear which creates political and economic turmoil in the short term with many other long-term consequences. Terrorists, as opposed to warfare, try to achieve their scopes without targeting the combatants and without directly hitting the decision makers (De Mesquita 2005). Terrorism can also be seen as an act of violence with the intention to disrupt the normal course of life to achieve political and economic gains (Enders et al. 2006; Enders - Sandler 1996).

Foreign direct investments (FDI) represent one of the key generators of economic growth. FDI can provide income, capital, technology, expertise, and market access. Tarzi (2005) identified the key factors of investment inflow in a country, i.e. to determine why certain countries have high FDI inflows, while inflows in other countries are minimal. The most important identified factors are market size, market growth rate, competitiveness of the economy, infrastructure, and productivity of the employees. The author pointed out the importance of legislation in the host country with a focus on the policies that encourage investment, taxation, repatriation, rules for property acquisition for foreign citizens, FDI regulations, labour policy, etc. He considered company characteristics, such as company size, business sector, types of industry, and strong and sustainable strategies as well. Emphasis was also placed on product differentiation factors, among which the most important factors are technology, brand, marketing activities, skills, logistics, and organisation, that can be the foundations of international competitiveness of a company.

In the neoclassical growth models, FDI promotes the creation of capital stock, enhances productions and thus impacts the economic growth (under certain conditions). FDI relates to technology transfer as well. FDI is believed to have positive short-term and long-term effects. (Roman 2012).

FDI requires an investment friendly and conducive environment in the host country (Buckley et al. 2002). In other words, if terrorist activities reduce security and investor's confidence they would reduce the inflow of FDI. High risk without a potential increase in the expected return on investment will drive foreign investment away from the host country (Shahzad et al. 2016). 
The costs of anti-terrorist security measures burden the economy and reduce its economic potential (Bezić et al. 2016). In the short run, terrorism results in material losses, casualties and creation of a negative investment climate. In the long run, international terrorism may affect inflation due to increased spending on national security and anti-terrorist activities. Negative consequences can be seen in sectors, like tourism, transport, etc. The terrorist attack in the USA in 2001 showed that terrorism can have negative effects on sectors or branches of industry (air transport and tourism) (Drakos 2004; Ito - Lee 2004) and resulted in a drastic increase in spending necessary for maintaining national security (Enders - Sandler 2006). In this way, security costs are incurred by all the users of products in the international market, in addition to the country threatened by terrorism.

Terrorism (and civil wars) may cause overflow of costs among neighbouring countries and divert capital inflows in the event of security risks in the neighbouring countries. An increased danger of terrorism may reduce economic activity across an entire region (Bezić et al. 2016). Terrorism also increases the operating costs, which are reflected in high insurance premiums, higher spending on security and higher wages for employees at risk.

There is a distinction between transnational terrorism and within-country terrorism. Mickolus et al. (2009) defines it as "the use, or threat of use, of anxietyinducing, extra-normal violence for political purposes by any individual or group, whether acting for or in opposition to established governmental authority, when such action is intended to influence the attitudes and behavior of a target group wider than the immediate victims and when, through the nationality or foreign ties of its perpetrators, its location, the nature of its institutional or human victims, or the mechanics of its resolution, its ramifications transcend national boundaries." In other words, domestic terrorism occurs within the boundaries of a certain country while international terrorism occurs outside country's boundaries and jurisdiction.

This research is based on the hypothesis that terrorist incidents have measurable impact on the FDI flows of developed countries. It is assumed that terrorist incidents have significant negative impact on inward FDI but insignificant in case of FDI outflows. The main objective of our research is to analyse and define institutional, economic, natural and terrorism dimensions and test their impact on the capital flows in 36 developed countries and propose measures to improve the level of security and to create a safe environment for investment.

Although the majority of research articles put attention on FDI inflows of various groups of countries, this study includes FDI inflows and outflows as separated concepts for the developed countries. FDI inflows and outflows are estimated using advanced econometric method: the (two step) GMM estimator which eliminates potential problems of endogeneity. 
Although the developing countries are more frequently targeted, the developed countries also pay a price. According to the Global Terrorism Index (2017), there were nearly 10,000 deaths from terrorism in OECD member countries between 1970 and 2016. In 21 out of 34 OECD countries, the year 2015 brought at least one terrorist attack with most of the deaths occurring in Turkey and France.

After the introduction, the second section is a review of the literature. Our methodological framework is presented in the third section. The fourth section presents our econometric model. The fifth section shows the results and the final section sets out our proposals and concluding observations.

\section{LITERATURE REVIEW}

Enders - Sandler (1996) found that terrorism discouraged net FDI by 13 per cent annually in Spain and 12 per cent annually in Greece in the period from 1975 to 1995. The authors stated that the smaller countries that face a persistent threat of terrorism may incur economic costs in the form of reduced investment and economic growth. Research conducted by Abadie - Andeazab (2003) was based on the insight that terrorist activities and increased global insecurity had a negative impact on the distribution and transfer of capital and investment inflows. Their results indicate that a standard deviation increase in the risk of terrorism is connected with a fall in net FDI of about 5\% of GDP.

Blomberg - Mody (2005) analysed the impacts of terrorism, wars and revolutions using a gravity model of bilateral FDI flows that included 12 countries of origin and 43 host countries in the period of 1981-1988. This model separated the effects of terrorism on FDI from impact of other forms of insecurity/violence on FDI. The findings, for the most part applicable to developing countries, showed that insecurity and violence in the host countries had a negative and significant effect on FDI while, on the other hand, insecurity/violence in the country of origin results in an outflow of FDI. Lutz - Lutz (2006) measured the impact of terrorism on FDI in 23 Latin American countries during 1969-1988 and confirmed significant negative impact of terrorism on FDI inflows. Kang - Lee (2007) found that terrorism was negatively and significantly related to FDI inflows of 83 countries during the 1980-2002 period.

Alomar-El-Sakka (2011) showed the same relationship in 136 less developed countries. Filer - Stanišić (2012) confirmed the impact of terrorism on capital flows in over 160 countries during a 25 -year period. According to these authors, terrorist attacks had negative impact on FDI, but no impact on external debt or portfolio investments. Powers - Choi (2012) analysed 123 developing countries from 1980 to 2008 and revealed that transnational terrorism weakened FDI. 
Omay et al. (2013) found that the intensity of the terrorist events influenced the impact of terrorism on FDI. Terrorist attacks of high intensity have bigger influence on the FDI inflows compared to lower intensity terrorist attacks.

Bandyopadhyay et al. (2014) investigated the impact of terrorism on the share of FDI in GDP of 78 developing countries for the period between 1984 and 2008. Their study distinguished the adverse consequences of domestic terrorism on FDI from those of transnational terrorism. They concluded that both types of terrorism depress FDI. Ezeoha - Ugwu (2015) found that the conflicts and terrorism attacks in 41 African countries had negative impacts on FDI inflows over the period of 1997 to 2012 and the institutional development moderated this influence.

Bezić et al. (2016) examined the effects of terrorism on inward FDI of $29 \mathrm{EU}$ and European Economic Area member countries from 2000 to 2013. Their results indicate negative and statistically significant impact of terrorism on per capita FDI inflow.

We note, however, that some studies did not confirm the impact of terrorism on FDI. One of them is $\mathrm{Li}$ (2006), who differentiated the anticipated and unanticipated terrorism and reported that neither of them had a direct impact upon FDI. A research by Younas (2009) implies that domestic and interstate conflicts are not determinant factors of FDI inflows.

\section{METHODOLOGY}

In this paper, the impact of terrorism on capital flows (measured by inward and outward FDI) of the developed countries is examined using the system GMM two-step dynamic panel method with asymptotic standard errors function.

To provide unbiased results, we have chosen the two-step estimator technique. The two-step estimator is asymptotically efficient and robust to whatever patterns of heteroskedasticity and cross-correlation between the sandwich covariance estimators exist. On the other side, some researchers often reported one-step results as well because of the downward bias in the computed standard errors in the twostep estimator. Furthermore, the one-step GMM has certain limitations (Ullah et al. 2018). In order to avoid potential data loss owing to the internal transformation problem with the first-step GMM, Arellano - Bover (1995) recommended the use of a second order transformation (two-step GMM).

Two forms of dynamic estimators were created while implementing GMM methods: differentiated GMM estimator (Arellano - Bond 1991) and system GMM estimator (Arellano - Bover 1995; Blundell - Bond 1998). Differentiated and system GMM estimators have been created for dynamic panel analysis and have certain assumptions on data generating process (Roodman 2009a), such as: 
- there is a possibility of autonomously distributed individual time-invariant effects,

- such a situation is contrary to the temporal regression model,

- some of the regressors can be endogenous,

- the occurrence must be dynamic in nature, with the realisation of the current dependent variable that is influenced by the variable from former periods,

- idiosyncratic disorders (except for time-invariant effects) have specific forms of heteroscedasticity, autocorrelation, and

- idiosyncratic disorders are uncorrelated between individual variables.

The dynamic model with a single time-shifted (lagged) variable can be shown by the following equation (1):

$$
y_{i t}=\beta y_{i t-1}+u_{i}+v_{i t},|\beta|<1,
$$

where $y_{i t}$ is the value of the dependent variable in period $t ; y_{t-1}$ is the dependent variable with a shift (lag) for one period from $t ; u_{i}$ are individual time-invariant effects, and $\mathrm{v}_{\mathrm{it}}$ is the random error. Individual impacts are treated as stochastic and a further assumption that is crucial for the consistency of the model is that errors $\mathrm{v}_{\mathrm{it}}$ are serially uncorrelated. Individual time-invariant effects are initially associated with the former influence of the dependent variable of the model, which points to the above-mentioned problem of endogeneity.

The GMM model removes endogeneity by "internally transforming the data"transformation refers to a statistical process where a variable's past value is subtracted from its present value (Roodman 2009b: 86).

In exceptional cases, when there is no serial correlation (autocorrelation) in the random error, the lagged differences, i.e. shifts of endogenous variables can be included as the instruments of the model (Arellano - Bond 1991; Greene 2005; Stojčić et al. 2011; Stojčić - Hashi 2011; Stojčić et al. 2012).

Inward and outward FDI values are transformed in natural logarithms. The same case is for GDP per capita variable. We expect visible impact of natural disasters on FDI inflows and outflows per capita. It is also assumed that the economic variable GDP per capita has a certain effect in the context of an increase in the inward and outward FDI stock per capita. The variables for capital openness and financial freedom should have a positive sign, but different significance depending on the direction of FDI. FDI is a process that develops over time. Proving the above predictions may provide an answer to the question of significance of the impact of terrorism on the FDI flows of developed countries. These assumptions of the empirical part will be subjected to econometric testing in order to confirm the main hypothesis of our research. Based on the two separated 
models, relevant variables are selected and tested. The econometric models are created as it follows:

LNFDIPCinwardstock $_{i t}=\beta_{0}+\beta_{1} \operatorname{LNFDIPCinw}(-1)_{i(t-1)}-\beta_{2} \operatorname{INCIDENTS}_{i t}-$

$$
-\beta_{3} \text { DISASTERS }_{i t}+\beta_{4} \text { LNGDPpc }_{i t}+\beta_{5} \text { Kaopen }_{i t}+\sum_{t=2002}^{2016} y^{2} a r_{t}+u_{i t}+v_{i t}
$$

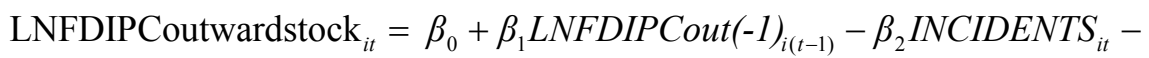

$$
-\beta_{3} \text { DISASTERS }_{i t}+\beta_{4} \text { LNGDPpc }_{i t}+\beta_{5} \text { Kaopen }_{i t}+\sum_{t=2002}^{2016} \text { year }_{t}+u_{i t}+v_{i t}
$$

Inward FDI stock per capita (LNFDIPCinwardstock) is selected to be a dependent variable in the econometric model (2) and outward FDI stock per capita (LNFDIPCoutwardstock) represents dependent variable of another econometric model (3). FDI stocks are the accumulated values held at the end of the reference period (typically year or quarter). The data are taken from the reference database UNCTAD (2017).

The following variables were selected as independent variables of the model, including the natural logarithm of the state of incoming FDI from the previous year (LNFDIPCinw (-1) for inward FDI stock and LNFDIPCout(-1) for outward FDI stock), the number of incidents (INCIDENTS), natural logarithm GDP per capita (LNGDPpc), the KAOPEN Index (Kaopen), and natural disasters (DISASTERS). LNFDIPCinw(-1) and LNFDIPCout(-1) represent the state of inward and outward foreign direct investment per capita respectively in the previous year and, simultaneously, the time-shifted variable.

Another independent variable is the INCIDENTS variable that represents the total number of terrorist attacks, i.e. incidents. This category is calculated as the sum of the injured people and fatalities from terrorist attacks. The data were collected from the Global Terrorism Database (2017). A number of empirical studies (Kang - Lee 2007; Agrawal 2011; Bandyopadhyay et al. 2014; Bezić et al. 2016; Filer - Stanišić 2016) include the number of terrorist incidents and/or casualties of terrorism as independent variables of the model. The conducted studies generally confirm the negative impact of terrorism on FDI. Therefore, in this study, the variable INCIDENTS is selected, which measures the impact of terrorism on inward and outward FDI stocks of developed countries.

The model includes natural logarithm of the variable GDP per capita ( $L N G D P$ $p c$ ). The values of GDP per capita of the observed countries were collected from UNCTAD (2017). GDP values are initially denominated in US dollars. The equation of the model involves the so-called Chinn-Ito (KAOPEN) Index measuring 
observed countries' degree of capital account openness. Kaopen represents the institutional variable of the model and at the same time shows the characteristics of the financial climate in a particular country. The KAOPEN Index is based on binary dummy variable that shows the limitations of cross-border financial transactions of the Annual Report on Exchange Arrangements and Exchange Restrictions (AREAER) by the IMF. The Index was originally developed by Chinn - Ito (2006) and is applicable to the studies of the impact of terrorism on FDI by Filer - Stanišić (2016). The econometric calculation includes the variable of natural disasters (DISASTERS), whose data were downloaded from the International Disasters Database (2017). The natural disaster variable is treated as an independent variable in studies by Filer - Stanišić $(2012$, 2016), Sanjo (2011), who confirm the negative impact of natural disasters on FDI. The variable $u$ indicates the individual time-fixed effects, while $v$ represents the random error of the model. The impact of omitted variables is measured by the effects of the constant.

\section{EMPIRICAL DATA AND ANALYSIS}

Our results relate to the period from 2000 to 2016 and include 516 (Equation 2) and 518 observations (Equation 3) from 36 developed countries. Our sample includes the Northern American countries (USA, Canada), the developed Asian and Pacific Countries (Australia, Japan, New Zealand), and 27 EU countries plus Switzerland, Norway, and Iceland.

By using a dynamic model, the potential problems of endogeneity and measured errors can be eliminated by using instruments, i.e. temporal shifts (lags) of the dependent variable. Implementation of the dynamic panel eliminates the problems that can affect reliability and assessment of the results of the empirical analysis. The diagnostics of the model is conducted first, and the impact will be tested by the selection of the dynamic panel. The significance of the impact of terrorist incidents and other independent variables on FDI inflow is tested by using the system two-step GMM estimator. The dynamic panel analysis is performed by the econometric software GRETL. The results indicate the impacts of the selected independent variables of FDI stocks from the previous year (LNFDIPCinw $(-1)$ and LNFDIPCout(-1)), the number of incidents (INCIDENTS), GDP per capita $(G D P p c)$, the values of KAOPEN Index (Kaopen), and natural disasters (DISASTERS) on two dependent variables LNFDIPCinwardstock and LNFDIPCoutwardstock. The results of the assessment and diagnosis of the dynamic panel model are presented on the example of the above mentioned dependent variables. Detailed printout of the results of the system two-step GMM estimator can be found in Table Al (Appendix). 
Table 1 shows two different results. The left side (Model (2)) results indicate the impacts of terrorism and other variables on inward FDI stock. The right side (Model (3)) results measure the impacts of terrorism and other variables on outward FDI stock of developed countries. The results of Wald test indicate satisfactory explanatory power of the variables for both models. Moreover, the respective significance of the test is confirmed for models (2) and (3). The synthesis of both diagnostic results implies that the model is well specified. Models are appropriate to econometric testing of the impact of independent variables on the inward and outward FDI stocks.

The resulting value (Prob $>$ chi2) of the Sargan test amounts to 1.0000 - higher than 0.05 , which means that both models are acceptable and correct. The ArellanoBond test is used to examine the existence of autocorrelation of the first (AR1)

Table 1. Results of the Dynamic Panel of System GMM Estimator from 2000 to 2016 (dependent variables LNFDIPCinwardstock (2) and LNFDIPCoutwardstock (3))

\begin{tabular}{l|c|l|c}
\hline Independent variables (2) & Value & Independent variables (3) & Value \\
\hline $\begin{array}{l}\text { Lagged dependent variable } \\
\text { LNFDIPCinw(-1) }\end{array}$ & $0.723686^{* * *}$ & $\begin{array}{l}\text { Lagged dependent variable } \\
\text { LNFDIPCout(-1) }\end{array}$ & $0.669763^{* * *}$ \\
\hline INCIDENTS & $-0.00152372^{* * *}$ & INCIDENTS & 0.000322894 \\
\hline DISASTERS & $-0.0134141^{* * *}$ & DISASTERS & $-0.0101781^{* * *}$ \\
\hline LNGDPpc & $0.243016^{* * *}$ & LNGDPpc & $0.762484^{* * *}$ \\
\hline Kaopen & 0.00755836 & Kaopen & $0.0267862^{* * *}$ \\
\hline Constant & $0.199837^{* *}$ & Constant & $-4.84173^{* * *}$ \\
\hline MODEL DIAGNOSTICS & VALUE & MODEL DIAGNOSTICS & VALUE \\
\hline Number of observations & 518 & Number of observations & 516 \\
\hline Number of instruments & 124 & Number of instruments & 124 \\
\hline Wald test & 16891,5 & Wald test & 90954,3 \\
\hline Prob>chi2 & 0.000 & Prob>chi2 & 0.000 \\
\hline Sargantest & 34.6841 & Sargantest & 1.0000 \\
\hline Prob>chi2 & 1.0000 & Prob>chi2 & 2.51333 \\
\hline $\begin{array}{l}\text { Arellano-Bond test } \\
\text { for AR(1) in the first } \\
\text { differences }\end{array}$ & 2.90837 & $\begin{array}{l}\text { Arellano-Bond test } \\
\text { for AR(1) in the first } \\
\text { differences }\end{array}$ & \\
\hline Prob>chi2 & & Prob>chi2 & 0,0120 \\
\hline $\begin{array}{l}\text { Arellano-Bond test for } \\
\text { AR(2) } \\
\text { in the first differences }\end{array}$ & -1.29508 & $\begin{array}{l}\text { Arellano-Bond test } \\
\text { for AR(2) in the first } \\
\text { differences }\end{array}$ & -1.00313 \\
\hline Prob>chi2 & 0.1953 & Prob>chi2 & 0.3158 \\
\hline
\end{tabular}

Note: P-values are represented with labels ***, which indicate the level up to $1 \%$ significance, and labels **, which indicate the level up to $5 \%$ significance. P-values were obtained by calculating the two-step dynamic procedure.

Source: Authors' calculations. 
and the second order of errors (AR2) in the first differences of the equations. Furthermore, the results of the Arellano-Bond (2) tests for both models do not indicate the presence of second-order autocorrelation due to bigger coefficients, which are much higher than the allowable limit of 0.05 (0.19 and 0.31). Therefore, the null hypotheses of no second-order autocorrelation are fully accepted. The coefficients have the expected signs and satisfactory statistical significance.

\section{RESULTS AND DISCUSSION}

After reviewing the model diagnostics, the results are interpreted by a two-step GMM estimation. There is a difference between the results of left and right side of Table 1. Model (2) and Model (3) indicate positive and highly significant coefficient of temporally shifted (lagged) dependent variables, which supports the thesis that the current values are positively related to the previous realisations.

In case of Model (2) the magnitude of the coefficient shows that $1 \%$ increase in the value of inward FDI stock per capita from the previous period results in an increase of $0.72 \%$ in the current period, keeping other variables of the model constant. The coefficient of Model (3) indicates that 1\% increase in outward FDI stock per capita from the previous period results in an increase of $0.66 \%$ in the current period, given the other variables of the model unchanged. The results indicate no statistical significance for outward FDI stock per capita. The fact is that the developed countries represent the world's major FDI investors. Therefore, domestic terrorist incidents could not have a strong impact on their FDI, which is often oriented towards the developing and less developed countries.

From Model (2)'s perspective, the inward FDI stock per capita will be reduced by $0.0001 \%$ if the number of incidents increases by $1 \%$, ceteris paribus. Also, there is no significance for the impact of variable INCIDENTS in Model (3). This number is lower than research results of Filer - Stanišić (2012). They used fixed effects estimation method which measured the impact of terrorist incidents on FDI from 1980 to 2008 and their estimated coefficient is -0.0534 with $10 \%$ level of significance. Kang - Lee (2007) also measured the impact of terrorist incidents on FDI by using the dynamic panel system estimation and found the coefficient is -0.003 with $5 \%$ level of significance. Their model includes 811 observations within the period from 1980 to 2002 . Therefore, these results indicate that FDI inflows of developed countries remained significantly negatively correlated with terrorist activities. Moreover, the impact is weaker than others. We conclude that the variables $L N F D I P C i n w(-1)$ and $L N G D P p c$ have strong impact on current FDI 
inflows of the developed countries. This is not the case for terrorist incidents which experience a small but significant drop in FDI inward stock of the developed countries.

The value of inward FDI per capita results in an increase of $0.24 \%$ if GDP per capita is increased by $1 \%$ provided the other variables of Model (2) remain constant. The coefficient of Model (3) shows that $1 \%$ increase in $L N G D P p c$ results in an increase of $0.76 \%$ of inward FDI stocks provided the other variables of the model remain constant. The outward FDI stocks per capita (Model (3)) decrease by $0.02 \%$ if the variable Kaopen increases by $1 \%$, given the other variables of the model remain same. In the case of Model (3), the Kaopen variable has the expected sign, but its significance is unsatisfactory. The DISASTERS variable has statistically significant impact on dependent variables of both models. In Model (2), inward FDI stock per capita will be reduced by $0.01 \%$ if the number of incidents increases by $1 \%$, ceteris paribus. The same value reflects on the relationship between disasters and outward FDI stock per capita (Model (3)).

The results imply negative and statistically significant impact of terrorism on inward FDI stocks per capita but not on outward FDI stocks per capita. The impact of Kaopen variable on inward FDI stocks per capita is relatively weak and insignificant while it recorded significant impact on outward FDI stocks per capita. Statistically significant impacts of GDP per capita on the dependent variables are recorded in both models. The highly significant impact of the disasters on inward and outward FDI stocks per capita has been confirmed as well. The process of FDI flows develops over a period and one should not ignore the fact that FDI flows may depend on FDIs from the previous periods. It is evident that direct foreign investments do not provide short-term but long-term, tangible results.

The results of both models (2) and (3) can be summarised in the following statements. Natural disasters occurring in developed countries certainly play a negative role in attracting/sending FDI. Higher level of economic performance (GDP per capita) stimulates higher concentration of FDI flows of developed countries as well. The developed countries with more FDI stock a year before tend to attract/send more FDI during current year. However, terrorist incidents proved to be negatively and significantly related only in case of FDI inward stock of the developed countries.

\section{CONCLUSIONS}

The key contribution of this research is that there exists a relationship between terrorist incidents and capital flows (FDI inflows and FDI outflows). The literature has already implied that FDI inflows are negatively related to terrorism. The 
present research covers a total of 36 developed countries for years 2000-2016. The results of the two-step GMM estimator take two types of capital flows into account. The main hypothesis of the research is confirmed, stressing out that "terrorist incidents have visible impacts on capital flows of the developed countries". However, the authors detected different significance levels of the impacts on FDI inflows and outflows. An occurrence of terrorism in developed countries does not have strong impact on their FDI outflows. Therefore, it is evident that there could not be any visible, negative spillover effects because of a different geographical location of FDI destination. The occurrence of major or infamous terrorist attacks causes reduction in FDI inflows, rise in security costs and weaker demand for products/services (especially in tourism and transportation sectors). It must be noted that the impact of terrorism on FDI inflows and outflows is significantly weaker than the impact of economic indicators (GDP growth), natural disasters (hurricanes, earthquakes, floods, etc.) and institutional factors (country's degree of capital account openness). Just like the case of the impact of terrorism, the impact of country's level of capital account openness recorded different impacts on capital flows. An implementation of the two-step GMM estimator of dynamic panel analysis provided more non-bias and objective scientific results.

The developed countries represent relevant and vital source of FDI. If we include into our analysis natural disasters as a factor, their negative impacts become more frequent and more destructive not only for the countries population and infrastructure but also for their capital flows. The consequences of political tensions (like wars, riots, etc.) also have strong influence on capital flows. The developed countries should be more aware of security problems and the relationship between terrorism and capital flows. We recommend that the developed countries systematically invest in national defense to prevent or minimise potential costs of terrorist activities. This activity requires the creation of national strategies which will neutralize or minimise any occurrence of security or economic crisis. Terrorism stimulates security measures and control which represent costs for developed countries. Moreover, terrorism proved to deteriorate foreign trade activities, which results in decline of trade volume. The countries receiving FDI should anticipate changes brought about by the increase in their political risk. The negative consequences of terrorist incidents discourage investors' motivation which proved to be an essential factor of FDI flows. However, it must be pointed out that, in some cases, terrorist activities could positively affect FDI flows (manufacture of guns and armory). The application of the results of this research may contribute to a clearer perception of the impacts of terrorism on FDI inflows and outflows. In closing, we stress again that the authors limited the investigation to the developed countries. Therefore, the findings of the present study might be different from those of other groups of countries selected (developing and under- 
developed countries). Depending on the goals of interested researches, businessmen and regulators, it is possible to include additional explanatory variables like military expenses, inflation, trade openness, infrastructure, political stability, etc. The model can be estimated by alternative econometric methods and the results can be compared. However, these drawbacks do not influence the significance of our research findings.

\section{REFERENCES}

Abadie, G. - Gardeazabal, J. (2003): The Economic Costs of Conflicts: A Case Study of the Basque Country. The American Economic Review, 93(1): 113-132.

Agrawal, S. (2011): The Impact of Terrorism on Foreign Direct Investment: Which Sectors are More Vulnerable? CMC Senior Theses, No. 124.

Alomar, M. - El-Sakka, T. (2011): The Impact of Terrorism on the FDI Inflows to Less Developed Countries: A Panel Study. European Journal of Economics, Finance and Administrative Sciences, 28: 116-125.

Arellano, M. - Bond, S. (1991): Some Tests of Specification for Panel Data: Monte Carlo Evidence and an Application to Employment Equations. The Review of Economic Studies, 58(2): 277-297.

Arellano, M. - Bover, O. (1995): Another Look at the Instrumental Variable Estimation of ErrorComponents Model. Journal of Econometrics, 68(1): 29-51.

Bandyopadhyay, S. - Sandler, T. - Younas, J. (2014): Foreign Direct Investment, Aid, and Terrorism: An Analysis of Developing Countries. Oxford Economic Papers, 66(1): 25-50.

Bezić, H. - Galović, T. - Mišević, P. (2016): The Impact of Terrorism on the FDI of the EU and EEA Countries. Zbornik radova Ekonomskog Fakulteta u Rijeci: časopis za ekonomsku teoriju i praksu/Proceedings of Rijeka Faculty of Economics. Journal of Economics and Business, 34(2): 333-362.

Blomberg, B. - Moby, A. (2005): How Severly Does Violence Deter International Investment? Claremont Colleges Economics Departments, Working Paper, No. 2005-01.

Blomberg, S. B. - Hess, G. D. - Orphanides, A. (2003): The Macroeconomic Consequences of Terrorism. Journal of Monetary Economics, 51(5): 1007-1032.

Blundell, R. - Bond, S. (1998): Initial Conditions and Moment Restrictions in Dynamic Panel Data Models. Journal of Econometrics, 87(1): 115-143.

Buckley, P. - Clegg, J. - Wang, C. - Cross, A. (2002): FDI, Regional Differences and Economic Growth: Panel Data Evidence from China. Transnational Corporations, 11(1): 1-28.

Çinar, M. (2017): The Effects of Terrorism on Economic Growth: Panel Data Approach. Zbornik radova Ekonomskog Fakulteta u Rijeci: časopis za ekonomsku teoriju i praksu/Proceedings of Rijeka Faculty of Economics. Journal of Economics and Business, 35(1): 97-121.

Crisis Management Web Analytics (2017): http://www.riskmap.aon.co.uk/Terrorism_Risk_Map. aspx.

Dabrowski, M. (2016): The Arab and Post-Communist Transformations: Similarities, Differences and Common Lessons. Acta Oeconomica, 66(2): 181-212.

De Mesquita, E. B. (2005): The Quality of Terror. American Journal of Political Science, 49(3): 515-530. 
Drakos, K. (2004): Terrorism-Induced Structural Shifts in Financial Risk: Airline Stocks in the Aftermath of the September 11th Terror Attacks. European Journal of Political Economy, 20(2): 435-446.

Enders, W. - Sandler, T. (1996): Terrorism and Foreign Direct Investment in Spain and Greece. Kyklos, 49(3): 331-352.

Enders, W. - Sandler, T. (2006): The Political Economy of Terrorism. Cambridge University Press, 3rd Edition.

Enders, W. - Sachsida, A. - Sandler, T. (2006): The Impact of Transnational Terrorism on US Foreign Direct Investment. Political Research Quarterly, 59(4): 517-531.

Ezeoha, A. E. - Ugwu, O. J. (2015): Interactive Impact of Armed Conflicts on Foreign Direct Investments in Africa. African Development Review, 27(4): 456-468.

Filer, R. K. - Stanišić, D. (2012): The Effect of Terrorist Incidents on Capital Flows. CESifo Working Paper Series, No. 3998.

Filer, R. - Stanišić, D. (2016): The Effect of Terrorist Incidents on Capital Flows. Review of Development Economics, 20: 502-513.

Global Terrorism Database (2017): https://www.start.umd.edu/gtd/

Global Terrorism Index (2016): http://economicsandpeace.org/wp-content/uploads/2016/11/ Global-Terrorism-Index-2016.2.pdf

Global Terrorism Index (2017): https://reliefweb.int/sites/reliefweb.int/files/resources/Global\%20 Terrorism\%20Index\%202017\%20\%284\%29.pdf

Greene, W. H. (2005): Econometric Analysis. (5th International Edition), Prentice Hall.

International Disasters Database (2017): http://www.emdat.be

Ito, H. - Lee, D. (2004): Assessing the Impact of the September 11 Terrorist Attacks on US Airline Demand. Journal of Economics and Business, 57(1): 75-95.

Kang, S. J. - Lee, H. S. (2007): Terrorism and FDI Flows: Cross-Country Dynamic Panel Estimation. Journal of Economic Theory and Econometrics, 18(1): 57-77.

Li, Q. (2006): Political Violence and Foreign Direct Investment. In: Fratianni, M. (ed.): Research in Global Security Management. Volume 12, Regional Economic Integration, Oxford: Elsevier, pp. 231-250.

Lutz, J. - Lutz, B. (2006): International Terrorism in Latin America: Effects on Foreign Investment and Tourism. Journal of Social, Political and Economic Studies, 31(3): 321-338.

Melnyk, L. - Kubatko, A. - Pysarenko, S. (2014): The Impact of Foreign Direct Investment on Economic Growth: Case of Post Communism Transition Economies. Problems and Perspectives in Management, 12(1).

Mickolus, E. F. - Sandler, T. - Murdock, J. M. - Flemming. J. (2009): International Terrorism: Attributes of Terrorist Events, 1968-2007. Dunn Loring, VA: Vinyard Software, Inc.

Omay, T. - Araz-Takay, B. - Eruygur, A. - Ilalan, D. (2013): The Effects of Terrorist Activities on Foreign Direct Investment: Nonlinear Evidence from Turkey. Review of Economics, 64(2): $139-158$.

Roman, M. D. - Padureanu, A. (2012): Models of Foreign Direct Investments Influence on Economic Growth. Evidence from Romania. International Journal of Trade, Economics and Finance, 3(1).

Roodman, D. (2009a): A Note on the Theme of Too Many Instruments. Oxford Bulletin of Economics and Statistics, 71(1): 135-158.

Roodman, D. (2009b): How to do Xtabond2: An Introduction to Difference and System GMM inStata. The Stata Journal, 9(1): 86-136.

Shahzad, S. J. H. - Zakaria, M. - Rehman, M. U. - Ahmed, T. - Fida, B. A. (2016): Social Indicators Research, 127(1): 179-194. 
Statistical Database UNCTAD (2017): http://www.unctad.org

Stojčić, N. - Bečić, M. - Vojinić, P. (2012): The Competitiveness of Exports from Manufacturing Industries in Croatia and Slovenia to the EU-15 Market: A Dynamic Panel Analysis. Croatian Economic Survey, 14(1): 69-105.

Stojčić, N. - Hashi, I. (2011): The Structure and Quality Upgrading of Croatian Exports to EU15 Market. Paper presented at the 9th International Conference, Challenges of Europe: Growth and Competitiveness - Reversing the Trends, Croatia, May 26-28.

Stojčić, N. - Hashi, I. - Shqiponja, T. (2011): Innovation Activities and Competitiveness: Empirical Evidence on the Behaviour of Firms in the New EU Member States and Candidate Countries. CASE Network Studies and Analyses, No. 424, Warsaw: CASE - Center for Social and Economic Research.

Tarzi, S. (2005): Foreign Direct Investment flows into Developing Countries: Impact Location and Government Policy. Journal of Social, Political and Economic Studies, 30(4): 497-515.

Tavares, J. (2004): The Open Society Assesses Its Enemies: Shocks, Disasters and Terrorist Attacks. Journal of Monetary Economics, 51(5): 1039-1070.

Ullah, S. - Akhtar, P. - Zaefarian, G. (2018): Dealing with Endogeneity Bias: The Generalized Method of Moments (GMM) for Panel Data. Industrial Marketing Management.

UN World Economic Situation Prospects Report (2017): https://www.un.org/development/desa/ dpad/wpcontent/uploads/sites/45/publication/2017wesp_full_en.pdf

Younas, J. (2009): Does Institutional Quality Affect Capital Mobility? Evidence from Developing Countries. Journal of Institutional Economics, 5(2): 207-223. 


\section{APPENDIX}

Table A1. Results of the System Two-Step GMM Estimator (inward and outward FDI)

Model 31: 2-step dynamic panel, using 518 observations

Included 35 cross-sectional units

Time-series length: minimum 7, maximum 14

Including equations in levels

$\mathrm{H}$-matrix as per $\mathrm{Ox} / \mathrm{DPD}$

Dependent variable: LNFDIPCinwardstock

Asymptotic standard errors

$\begin{array}{lclcrl} & \text { Coefficient } & \text { Std. Error } & \mathrm{z} & \mathrm{p} \text {-value } & \\ \text { LNFDIPCinw(-1) } & 0.723686 & 0.0119842 & 60.39 & <0.0001 & * * * \\ \text { const } & 0.199837 & 0.0868201 & 2.302 & 0.0213 & * * \\ \text { Kaopen } & 0.00755836 & 0.00572324 & 1.321 & 0.1866 & \\ \text { Incidents } & -0.00152372 & 0.000414243 & -3.678 & 0.0002 & * * * \\ \text { Disasters } & -0.0134141 & 0.00293386 & -4.572 & <0.0001 & * * * \\ \text { LNGDPpc } & 0.243016 & 0.0154328 & 15.75 & <0.0001 & * * *\end{array}$

$\begin{array}{lll}\text { Sum squared resid } \quad 51.42977 & \text { S.E. of regression }\end{array}$

0.316937

Number of instruments $=124$

Test for AR(1) errors: $\mathrm{z}=-2.90837$ [0.0036]

Test for AR(2) errors: $z=-1.29508$ [0.1953]

Sargan over-identification test: Chi-square $(118)=34.6841$ [1.0000]

Wald (joint) test: Chi-square $(5)=16891.5[0.0000]$

Model 30: 2-step dynamic panel, using 516 observations

Included 35 cross-sectional units

Time-series length: minimum 7, maximum 14

Including equations in levels

$\mathrm{H}$-matrix as per $\mathrm{Ox} / \mathrm{DPD}$

Dependent variable: LNFDIPCoutwardstock

Asymptotic standard errors

$\begin{array}{lclcrl} & \text { Coefficient } & \text { Std. Error } & \mathrm{z} & \mathrm{p} \text {-value } & \\ \text { LNFDIPCout(-1) } & 0.669763 & 0.0164873 & 40.62 & <0.0001 & * * * \\ \text { const } & -4.84173 & 0.218591 & -22.15 & <0.0001 & * * * \\ \text { Kaopen } & 0.0267862 & 0.00802801 & 3.337 & 0.0008 & * * * \\ \text { Incidents } & 0.000322894 & 0.000460820 & 0.7007 & 0.4835 & \\ \text { Disasters } & -0.0101781 & 0.00107775 & -9.444 & <0.0001 & * * * \\ \text { LNGDPpc } & 0.762484 & 0.0345005 & 22.10 & <0.0001 & * * *\end{array}$

$\begin{array}{llll}\text { Sum squared resid. } & 85.87350 & \text { S.E. of regression } & 0.410341\end{array}$

Number of instruments $=124$

Test for AR(1) errors: $\mathrm{z}=-2.51333[0.0120]$

Test for AR(2) errors: $z=-1.00313$ [0.3158]

Sargan over-identification test: Chi-square $(118)=34.3296[1,0000]$

Wald (joint) test: Chi-square $(5)=90954.3[0,0000]$ 